\title{
TRANSFORMING CUSTOMARY TITLE TO INDIVIDUAL TITLE: REVISITING THE CATHEDRAL
}

\author{
SAMANTHA HEPBURN*
}

[At the date of writing, the proposed amendments to the Aboriginal Land Rights Act 1976 (NT) endorsing the transfer of customary ownership to the Northern Territory government in exchange for a re-grant of a sub-lease, had not yet been passed. This article examines the rationalisations underlying this proposed change and the broader implications for customary ownership. Individuated title cannot accurately encompass the cultural foundations of indigenous ownership because it is sourced in a different ontological perspective. It is argued that the transformation of customary ownership into individual title will destroy its unique communal foundation, dislocate indigenous 'tenants' from their customary identity and produce a complex network of fractionalised interests. It is argued that such a shift is ultimately a retrograde step which, as experience in the United States and New Zealand has clearly shown, cannot provide an economic solution for remote indigenous communities.]

\footnotetext{
* LLB/BA (Mon); LLM (Melb); Phd (Melb), Senior Lecturer, Faculty of Business and Law, Deakin University.

I am indebted to the papers and discussion presented at the July 2006 Native Title Workshop, 'Trends Toward Individual Title over Communal Lands: Implications For Resource Management and Sustainability' University of Melbourne for providing inspiration and insight.
} 
Because our frame of reference takes itself to be the only way in which to conceive of something, it excludes other interpretations; because our conception of truth is one of universals and not simply varying portrayals, there is always to be an underlying referent. ${ }^{l}$

The change to an individual title would throw the whole of our domain in a few years into the hands of a few persons. ${ }^{2}$

To understand the cathedral one must see all of them. ${ }^{3}$

\section{INTRODUCTION}

This article critically examines the justifications and consequences underlying the proposals to transform customary Australian native title into individualised private title.

The proposal by the Northern Territory government to amend the Aboriginal Land Rights Act (NT) 1976 (hereinafter referred to as the ALRA) and permit Aboriginal customary owners to issue perpetual leases over their townships to government entities who would then be entitled to sub-lease those townships back to the customary owners, represents a dramatic shift in policy and proprietary evolution for native title. ${ }^{4}$ The

\footnotetext{
${ }^{1}$ B Bryan, 'Property as Ontology: On Aboriginal and English Understandings of Ownership' (2000) 13 Canadian Journal of Law and Jurisprudence 3 at 10.

${ }^{2}$ A memorial from the Creeks, Choctaws and Cherokees in 1888: Congressional Record, Jan 20, 781 from F S Cohen, Handbook of Federal Indian Law, first published 1941 (US Government Printing Office), $19454^{\text {th }}$ printing at 21.

${ }^{3}$ A reference to the comments first raised in the classic discussion by G Calabresi and A D Melamed, 'Property Rules, Liability Rules, and Inalienability: One View of the Cathedral' (1972) 6 Harvard law Review 1089 where the authors at fn 2 reiterate the idea that in order to understand Monet's depiction of the Cathedral at Rouen, all of his Cathedral paintings must be viewed. See G Hamilton, Claude Monet's Paintings of Rouen Cathedral 1960, 4-5 and 19-20.

${ }^{4}$ At the time of writing, the Bill was before the Senate. Debate on the issue has been expedited. As noted by S Brennan, 'Ideology makes for Dangerous Law' Australian Policy Online, Posted 10.8.06

http://www.apo.org.au/webboard/results.chtml?filename_num=94490: 'The government used the guillotine procedure to cut off debate in the lower house,
} 
legislative scheme underlying the proposals effectively involves the 'reconfiguration' of native title from an interest capable of embracing a culturally specific relationship with the land into an interest founded upon Western ownership ideology.

The proposed amendments may be briefly summarised as follows. The 'head-lease' held by the government entity would take the form of a perpetual lease capable of being issued for periods of up to 99 years. $^{6}$ The 'sub-lease' given back to customary owners would be similar to other nonfreehold interests in the sense that it would exist for a limited period, as agreed upon by the parties, but shorter in duration than the head-lease. ${ }^{7}$ The sub-lease would be governed in accordance with specific contractual and legislative regulations as is the case with other private leasehold interests. There would, however, be no obligation upon the government to 'consult' with communities holding native title rights in the area prior to the issuing of the sub-lease, provided it is clear that the customary owners or their representatives have 'agreed' in principle to the shift. ${ }^{8}$ Rent payments for the 'head-lease' held by the government would be payable from the Aboriginal Benefits Trust. ${ }^{9}$

These proposed amendments, if passed, would constitute a significant change to the existing legislation. Whilst the ALRA does enable interests or estates in land to be granted for residential, business and other purposes to Aboriginal people and to others, it is subject to Land Council consent and this practice has not been widespread. ${ }^{10}$

after less than three hours. A Senate committee had a one day hearing and a few days to write a report. Government senators said the process was 'totally inadequate' and 'such fundamentally important legislation should have bipartisan support with broad consensus among stakeholders affected.'

${ }^{5}$ For a more general discussion on the vision of property as a social creation see: M J Horwitz, The Transformation of American Law 1870-1960, 1992 at 151-156. See also K J Vandevelde, 'The New Property Of the Nineteenth Century: The Development of the Modern Concept of Property' (1980) 29 Buffalo Law Review 325.

${ }^{6}$ This is set out in the proposed section 19A, ALRA.

${ }^{7}$ This is set out in the proposed section 19(4A)

${ }^{8}$ See proposed section $19 \mathrm{~A}(14)$.

${ }^{9}$ See proposed section 19A(6),(8).

${ }^{10}$ See ALRA s19(2). See also the discussion on private ownership of indigenous communal land in: The Aboriginal Land Rights Act (Northern Territory) 1976, Building on Land Rights for the Next Generation (The 'Reeves Report) August, 1998 : Appendix F. The report ultimately found that the ALRA had been effective 
A number of rationalisations have been put forward to justify these developments. The primary one relates to economic well-being. It has been suggested that this type of shift is important because customary ownership is incapable of generating the same level of economic benefits that private ownership attracts. ${ }^{11}$ The individuated bundle of rights that private ownership encompasses, in particular its alienable status, is assumed to be more 'efficient' because the increasing resource value of land has simultaneously increased the benefits of authorised, marketable rights. $^{12}$

Supporting these assumptions, in April 2005 the Prime Minister John Howard stated:

I believe there is a case for reviewing the whole issue of Aboriginal land title, in the sense of looking towards private recognition ... I certainly believe that all Australians should be able to aspire to owning their own home and having their own business. Having the title to something is the key to your sense of individuality. ${ }^{13}$

However, there has been concern about the effect such a fundamental shift in policy may have upon the cultural integrity of customary ownership and indigenous communities generally. Professor Mick Dodson has suggested that the proposals would eventually result in the removal of communal,

in granting traditional Aboriginal land in the Northern Territory but that the costs had greatly exceeded the benefits.

${ }^{11}$ See for example the government comments in media releases where it is stated that these proposals will 'make it significantly easier for individuals to own their own homes and establish businesses' ('Government to reform Aboriginal land rights', The World Today, 31 May, 2006). See also the comments of researchers at the Centre for Independent Studies: in A New Deal for Aborigines and Torres Strait Islanders in Remote Communities (Professor Helen Hughes and J Warin) who stated: 'Private property rights in land are essential to attracting outside investment that is a pre-requisite to a major expansion in employment opportunities.' See: http://www.cis.org.au/IssueAnalysis/ia54/IA54.pdf ${ }^{12}$ See especially H Demsetz, Toward a Theory of Property Rights' (1967) 57 American Economic Review 347.

${ }^{13}$ Transcript of the Prime Minister, the Honourable John Howard MP, Doorstop interview, Wadeye, Northern Territory, 6 April 2005 at:

http://www.pm.gov.au/news/interviews/Interview1305.html 
customary ownership. ${ }^{14}$ Noel Pearson has argued that the proposals may be a 'trojan horse' resulting in a further 'taking away' of land rights from Aboriginal people. ${ }^{15}$

The 2005 Oxfam Australia report concluded that there was 'no evidence to suggest that individual land ownership is either necessary or sufficient to increase economic development or housing construction. ${ }^{16}$ In particular, the report noted that private ownership cannot effectively address the issue of housing and poverty needs for remote communities and that the "notion that land rights reform can be the main driver for economic development should be reconsidered in light of the legacy of disadvantage, cultural differences and structural factors faced by these communities. ${ }^{17}$

This article argues that a shift from customary ownership to individuated title, such as the one proposed by the Northern Territory government, is a retrograde step for the social, cultural and economic well-being of indigenous communities. The amendments to the ALRA have been proposed on the understanding that such a shift will increase economic prosperity for indigenous communities and encourage greater resource management. ${ }^{18}$ However, it is suggested that the overall consequence of such a transition would be a 'disaggregation' of 'the customary and communal elements of title. ${ }^{19}$ In effect, customary ownership would become individualised leasehold title. The potential social and proprietary ramifications of this include: significant and rapid loss of traditional, customary lands, the creation of confusing and disparate tenures and the loss of an enduring collective identity, manifest through customary ownership and its protection of cultural continuity.

\footnotetext{
${ }^{14}$ Land Rights Under Threat, Australians for Native Title and Reconciliation: http://www.antar.org.au/index.php?option=com_content\&task=view\&id=94\&Ite $\mathrm{mid}=104$

${ }^{15}$ The Australian, 14 April, 2005.

${ }^{16}$ Land Rights and Development Reform in Remote Australia, Oxfam Australia, (2005), 5 (prepared by J Altman, C Linkhorn, J Clarke, B Fogary and K Napier).

${ }^{17}$ Ibid. See also the discussion on the Bill: Aboriginal Land Rights (Northern Territory) Amendment Bill 2006 (Bills Digest n. 158, 2005-06)

${ }^{18}$ See generally: S Bradfield, 'White Picket Fence or Trojan Horse?' The debate over Communal Ownership of Indigenous land and Individual Wealth Creation' (2005) 3(3) Land, Rights, Laws: Issues of Native Title 1-10.

${ }^{19}$ M Tehan, 'Co-existence of interests in land: A Dominant Feature of the Common Law' (1997) Land, Rights, Laws: Issues of Native Title: Issues Paper No. 12, Native Titles Research Unit, Canberra: Australian Institute of Aboriginal and Torres Strait Islander Studies.
} 
The discussions in this article are divided into four sections. The first section examines the effect of title 'individuation' upon indigenous identity. Native title has been rationalised as a 'recognition' concept. ${ }^{20}$ That is, it is articulated as a concept based upon acknowledgement, validation and continuation of traditional cultural practices. ${ }^{21}$ Those practices must accord with fundamental common law assumptions however, the proprietary status of native title is not based upon its similitude with tenured estates and the 'bundle of rights' they attract. ${ }^{22}$ It is founded upon its position as an intercultural protective device. In the words of Noel Pearson, native title is 'the space between the two systems, where there is recognition. ${ }^{23}$

The transformation of native title from communal to individual would destroy its 'recognition' focus. As an individualised interest, native title would be reconceived in terms of proprietary rather than cultural status. ${ }^{24}$ It would enter a completely different ownership paradigm where individualised rights and self-preservation replace cultural acknowledgement and collective benefit.

One effect of this shift would be the 'splintering' of native title. Indigenous customs and traditions would be vulnerable to abuse, no longer nurtured under the protective umbrella of customary ownership. Native title would become an English property abstraction, created and regulated

\footnotetext{
${ }^{20}$ See N Pearson, 'The Concept of Native Title at Common Law' in Galarrwuy Yunupingu (ed) Land is Our Life: Land Rights - Past, Present and Future (1997) 150,154 where the author argues that native Title is, for want of a better formulation the recognition space between the common law and the Aboriginal law.'

${ }^{21}$ See the discussion by the Australian High Court in Yanner v Eaton (1999) 166 ALR 258 at 264 (per Gleeson CJ, Gaudron, Kirby and Hayne JJ) holding that the bundle of rights theory is an inadequate way of analysing customary ownership. See also K Barnett, 'Western Australia v Ward: One Step Forward and Two Steps Back: Native Title and the Bundle of Rights Analysis' [2000] 24 Melbourne University Law Review 462.

${ }^{22}$ See Mabo v Queensland [No 2] (1992) 175 CLR 1 at 59. See also Dr Strelein, 'Conceptualising Native Title' (2001) 23 Sydney Law Review 95 and G Werther, Self-Determination in Western Democracies: Aboriginal Politics in Comparative Perspective (1992) 68-72.

${ }^{23}$ Above n. 19

${ }^{24}$ The communal foundations of indigenous ownership is well established. Native American Indians perceived land ownership in terms of its use as 'ecological cornucopia' rather than 'tradeable commodity': W Cronon, Changes in the Land: Indians, Colonists and the Ecology of New England (1983) 63.
} 
by the common law rather than in accordance with the cultural processes reflective of time-honoured rights exercised by indigenous communities as a whole.

The destruction of communal land interests would, in the long term, be highly injurious to indigenous communities. Removing the cohesive influence of customary ownership could produce a social engineering that, in the context of American Indians, has been described as akin to 'legal cultural genocide. ${ }^{25}$

In the second section, the importance and utility of the 'communal' character of customary ownership is examined. It is argued that customary ownership is appropriately represented through shared, collective ownership. This reflects its cultural foundations. In most instances, proving the continuation of customs and traditions dating back to presovereignty times is only possible through integrated community behaviour and protocol. ${ }^{26}$ Whilst the Mabo High Court did not rule out the possibility of customary ownership being held by an individual, this has certainly not been the norm.

In the third section, the economic justifications underlying the shift to individuated title are explored. The fundamental notion, underpinning the individuation proposals is that a shift to private ownership will produce greater economic prosperity for indigenous communities. This assumption is re-examined. It is argued that the assumed 'efficiency' benefits are based upon economic suppositions that do not respond to different cultural conceptions of ownership. Customary ownership is not inherently amenable to 'resource' classification. The economic assumptions that regard 'private property' as an evolutionary process consequent upon rising resource values, overlook the fact that property rights reflect complex social phenomena. ${ }^{27}$ Thus, 'in circumstances of legal, normative

\footnotetext{
${ }^{25}$ See R Strickland, Genocide-at-Law: An Historic and contemporary View of the Native American Experience (1986) 34 Kansas Law Review 713, 721.

${ }^{26}$ See P Sutton, Native Title in Australia: An Ethnographic Perspective (2003) 16 where he discusses 'post-classical' cultural practices which have evolved since colonisation and which have regional and community characteristics.

${ }^{27}$ See generally the discussion in R C Ellickson, Order Without Law: How Neighbours Settle Disputes (1991).
} 
and institutional pluralism, [private] property rights will not necessarily emerge when resource users calculate that the gains from internalization outweigh the costs. ${ }^{28}$

Customary, communal property is founded upon an established normative order that regulates the management of land resources co-operatively and internally. A shift to private ownership would destroy this collaborative, cultural governance without addressing the significant social, geographical and structural concerns facing indigenous communities within remote areas. $^{29}$

Finally, the article examines the experiences of other countries that have adopted title 'individuation' policies. The 'allotment' period within the United States in the late nineteenth and early twentieth century is briefly explored as are the experiences of the Maori Land Court in New Zealand where, during the early settlement period, customary Maori ownership was routinely transferred into freehold title. The lessons that each of these jurisdictions provide is that the individuation of customary ownership is a product of a broader enframement process. The worldview that private ownership embodies, of land titles as items of wealth, consumption and exchange, threatens to displace the cultural integrity and cohesion of indigenous societies. ${ }^{30}$

\section{Reconceiving Native TitLe As INDIVIDUATEd titLe}

Put simply, title individuation refers to the process of transferring collective or communal land ownership into particularized, individual land grants. It is not a new concept. The early customary tenures that populated Scotland and Ireland were 'individuated' over the $16^{\text {th }}$ and $17^{\text {th }}$ centuries and replaced with fee-simple grants. ${ }^{31}$ This was, however, a product of the

\footnotetext{
${ }^{28}$ D Fitzpatrick, 'Evolution and Chaos in Property Rights Systems: The Third World Tragedy of Contested Access' (2006) 115 Yale Law Journal 996, 1009.

${ }^{29}$ Oxfam Australia, Land Rights and development reform in remote Australia, (2005) (prepared by J Altman, C Linkhorn, J Clarke, B Fogary and K Napier) 5.

${ }^{30}$ See the general discussion of this by R Devlin, 'When Legal Cultures Collide' in M Asch (ed), Aboriginal and Treaty Rights in Canada (1997).

${ }^{31}$ See J M Neeson, Commoners: Common Right, Enclosure and Social Change in England, 1720-1820 (1993); Armen A Alchian and Harold Demsetz, The Property Right Paradigm, (1973) 33 Journal of Economic History 16, 25
} 
imposition of feudal tenure and customary landholdings were repositioned to accommodate this framework. ${ }^{32}$

The process of individuating indigenous customary indigenous ownership into common law estates is far more dislocative than the historical experiences of early brehon or manorial customary tenure. ${ }^{33}$ The individuation of native title applies the univocal framework of the common law to the normative traditions of indigenous communities. It reconfigures indigenous ownership despite irreconcilable cultural differences between the 'ownership' trajectories. ${ }^{34}$ Individuated title is the antithesis of a title representing the 'intersection' or 'collision point' between common law and indigenous ownership and the "beliefs, customs and laws of community. ${ }^{35}$

The relatively recent acceptance by the Australian High court of the validity of native, customary ownership has meant that Australia, unlike New Zealand or the United States, has had no history or experience with the transformation of indigenous ownership into freehold title. Pre-Mabo, native title had no independent proprietary existence therefore there was no need or impetus to consider title individuation.

In the fourteen years since Mabo was handed down, the essential characteristics of native title have gradually taken shape. ${ }^{36}$ It has come to be accepted as fundamentally 'non-private' and 'communitarian' ${ }^{37}$ The

\footnotetext{
${ }^{32}$ See S Dorsett, 'Since Time Immemorial' A Story of Common Law Jurisdiction, Native Title and the Case of Tanistry' (2002) 26 Melbourne University Law Review 32.

${ }^{33}$ For a discussion of the experiences of early customary experiences see: $\mathrm{P}$ Goodrich, 'Eating Law: Commons, Common Land, Common Law' (1991) 12 Journal of Legal History 246.

${ }^{34}$ For a further discussion of this process see: Noel Pearson, 'Principles of Communal Native Title' (2000) 5 Indigenous Law Bulletin 4; Peter Rush, 'An Altered Jurisdiction: Corporeal Traces of Law' (1997) 6 Griffith Law Review 144. ${ }^{35}$ Yanner $v$ Eaton (1999) 166 ALR 258 at 277 per Gummow J.

${ }^{36}$ For a discussion on the evolution of native title see generally: R Bartlett, 'The Proprietary Nature of Native title' (1998) 6 Australian Property Law Journal 77; R Bartlett 'The Aboriginal Land Which May be Claimed at Common Law: The Implications of Mabo' (1992) 22 Western Australian Law Review 272, N Bhuta, 'Mabo, Wik and the Art of Paradigm Management' (1998) 22 Melbourne University Law Review 24.

37 See F Cohen 'Original Indian Title'(1932) Minnesota Law Review 28; J W Harris, 'Private and Non-Private Property: What is the Difference' (1995) 111
} 
connection with the land is established through communal traditions and practices rather than the individual expression of those traditions. ${ }^{38}$ Native title, as outlined by Dr Strelein:

is not the sum of individual rights in law, nor can it normally be held individually. It has a different character. It is the right of a group that can be asserted outwardly. Collective rights of Indigenous peoples emerge from their distinct status, identity and history. Collective rights therefore have a special function ... Collective rights are a sphere of authority and autonomy, capable of expression against the world. ${ }^{39}$

Collective rights carry a special status within indigenous communities, not only because they reflect an established connection with the claimed land, but also because they express the unique and autonomous character of indigenous identity. ${ }^{40}$ Cultural identity is manifested through the mutual expression of traditions and beliefs rather than autonomous, self-directed rights. $^{41}$

In Mabo v Queensland (No 2) the Australian High Court rejected the notion that the native title held by the Meriam people amounted to a fee simple estate by virtue of their prior possession. ${ }^{42}$ As Professor Harris has

Law Quarterly Review 421 for discussion on the nature and characteristics of communitarian and collective property as opposed to private property. See also L Strelein, 'Conceptualising Native Title' (2001) 23 Sydney Law Review 95.

${ }^{38}$ This is discussed by J Nedelsky, 'Reconceiving Rights as Relationship' in J Hard and H Bauman (eds), Explorations in difference: Law, Culture, and Politics (1997) 56.

${ }^{39}$ 'Conceptualising Native Title'above n.36 at 135.

${ }^{40}$ This is discussed generally by J E Magnet, 'Collective Rights, Cultural Autonomy and the Canadian State' (1986-87) 32 McGill Law Journal 170 especially at 176 where the author discusses the premise that individuals express themselves by being members of social groups and that in communities which enjoy 'or seek collective rights', participation is an indispensable condition for self-fulfillment.

${ }^{41}$ See J E Magnet, 'Collective Rights, Cultural Autonomy and the Canadian State' (1986) 32 McGill Law Journal 170 where the author discusses the importance of collective rights for Canadian minority groups and the need for them to be constitutionally protected.

${ }^{42}$ This argument was based upon that espoused by K McNeil, Common Law Aboriginal Title 1989. Toohey J was the only judge to support this argument: (1992) 175 CLR 1, 206-214. 
noted, if native title had been expressed so that indigenous groups became joint tenants of a fee simple estate, the Meriam people would have acquired 'joint property within the institution, not communitarian property recognised by the institution.' ${ }^{43}$ Thus, the validity and normative force of native title lies in its externalised status as a collective concept, dislocated from institutionalised proprietary assumptions. The social, spiritual and cultural bond shared by indigenous communities imbues native title with a distinctive and cohesive identity which is the 'historical and logical oppositum of ownership by a single proprietor. ${ }^{, 44}$

The replacement of communitarian title with individual title would destroy the common law acknowledgement of cultural 'otherness'. Native title exists in stark contrast to private property interests. Whilst the common law origins of native cannot be denied, it is unique because it amounts to a 'relationship between a community of indigenous people and the land, defined by reference to that community's traditional laws and customs, which is the bridgehead to the common law. ${ }^{45}$

Thus, native title has come to represent much more than a bundle of land oriented rights. It embodies the interface between indigenous tradition and the common law. Communal native title rights reflect broad notions of ownership and governance. The replacement of such an 'integrative' concept with structured, Eurocentric and highly 'propertised' titles would destroy this interface. It would shackle indigenous normative traditions to an institutionalised ownership spectrum. ${ }^{46}$

\footnotetext{
${ }^{43}$ See J W Harris, 'Private and Non-Private Property: What is the Difference?' (1995) 111 Law Quarterly Review 421, 436.

${ }^{44}$ See P Grossi, An Alternative to Private Property: Collective Property in the Juridical Consciousness of the Nineteenth Century (1981) (translated by L G Cochrane) 24.

${ }^{45}$ Yanner v Eaton (1999) 166 ALR 258, 278.

${ }^{46}$ For a further discussion on the multi-dimensional spectrum of modern property frameworks see C B Macpherson, 'Capitalism and the Changing Concept of Property' in E Kamenka and R S Neale (eds), Feudalism, Capitalism and Beyond (1975); K Gray and S Gray,' The Idea of Property in Land' in S Bright and J Dewar (eds), Land Law: Themes and Perspectives (1998).
} 


\section{CUSTOMARY OWNERSHIP AS A COMMUNAL CONCEPT}

When the proprietary concept of native title was first discussed by the Australian High Court in Mabo v Queensland [No 2], it was characterised as primarily communal in nature. Where a clan or group has continued to acknowledge laws and traditions dating back to pre-sovereignty, so that a traditional connection with the land has been substantially maintained, the court concluded that traditional communal title will endure. ${ }^{47}$ This is not to suggest that native title may never be held by a single claimant. Section 223(1) of the Native Title Act (Cth) 1993 explicitly recognises that native title may include not only communal rights and interests, but group or individual rights or interests, provided they are in relation to land or waters. ${ }^{48}$ However at core, the common law concept of native title is a communal one. As explicated by Brennan J:

[T]he people remain as an identifiable community, the members of whom are identified by one another as members of that community living under its laws and customs, the communal native title survives to be enjoyed by the members according to the rights and interests to which they are respectively entitled under the traditionally based laws and customs, as currently acknowledged and observed.

Similarly, in Western Australia v Ward, the court noted that the critical feature of customary ownership is proof of a continuing connection with the land and it is not necessary 'to spell out the personal or usufructuary rights of particular individuals within the community.' ${ }^{49}$

In most instances, it is the community as a whole rather than individual members who are equipped to discharge the onerous burden of proof in a native title claim and establish the substantial maintenance of cultural traditions over claimed land. This is because indigenous customs are both constitutive and reflective of community practice. ${ }^{50}$

\footnotetext{
${ }^{47}$ Mabo v Queensland [No 2] (1992) 175 CLR 1, 59.

${ }^{48}$ This was also confirmed in Members of the Yorta Yorta Aboriginal Community v Victoria (2002) 214 CLR 422, [33].

${ }^{49}$ (2000) 99 FCR 316.

${ }^{50}$ See J Nedelsky, 'Reconceiving Rights as Relationship' in J Hart and R Bauman (eds), Explorations in Difference: Law, Culture and Politics (1996).
} 
If customary ownership is transformed into private ownership, whether freehold or otherwise, this fundamental communal foundation would be extinguished. The private enforcement of land right rights, particularly the right to alienate, would fundamentally shift community structure and relations. Instead of land ownership being managed by reference to the collective interests of the indigenous group as a whole, it would become segmented. This would have a disjunctive effect on community relationships and, potentially, a devastating effect on cultural continuity. ${ }^{51}$

The term 'community' has several different meanings for indigenous people. There are formal 'geographical' communities where the connection is based purely around mutual residence and the location of group members. There are also 'interspersed communities' where the connection is based upon cultural and spiritual attachment rather than geographical location. ${ }^{52}$ The latter form of community is coterminous with customary ownership because of its strong cultural foundations. Thus, customary ownership protects the relationship that members of a community, who may not necessarily have lived in that region, have with the claimed land. ${ }^{53}$

By contrast, private ownership is spatial and physical in its application. It entitles the holder to exclusively possess the land because it is a 'system of rules governing access to, and control of, materials resources. ${ }^{54}$

An indigenous holder of a private title would be entitled to carry out established customs and traditions, but only within the exclusively possessed area. If the holder was a part of an interspersed community and did not reside in the area, he or she would have to either relocate or alienate to a third party. Enforcement of customary laws and traditions would not be possible in the absence of individualised control because

\footnotetext{
${ }^{51}$ Ibid. See also the discussion on the distinction between private and non-private property by J W Harris, 'Private and Non-Private Property: What is the Difference?' (1995) 4 Law Quarterly Review 134.

52 This distinction is discussed by P Sutton, Native Title in Australia (2003) 99.

${ }^{53}$ See also, M Tehan, 'Co-existence of interests in land: A Dominant Feature of the Common Law' (1997) Land, Rights, Laws: Issues of Native Title: Issues Paper No. 12, Native Titles Research Unit, Canberra: Australian Institute of Aboriginal and Torres Strait Islander Studies.

${ }^{54}$ See the discussion by Jeremy Waldron, The Right to Private Property (1988) 218-220 and C B Macpherson, 'The Meaning of Property in C B Macpherson, (ed), Property, Mainstream and Critical Positions (1978.)
} 
private ownership is organised around this central 'exclusivity' tenet and is not reconcilable with the detached processes associated with customary ownership. ${ }^{55}$

Eventually, title individuation would fragment the communal foundation of customary ownership. Sections of individualised land would come to be exclusively controlled by individuals entitled to refuse access to other non -titled community members. The holistic interests of indigenous communities would be damaged by such fractionalisation. It would impede the capacity of customary owners to practice enduring customs and traditions. Indigenous members holding individualised titles would be dislocated from community groups and their social identity would be redefined. ${ }^{56}$

\section{A CRITICAL EXAMINATION OF ECONOMIC JUSTIFICATIONS}

It has been argued that communal, collective ownership cannot provide the economic prosperity that individuated title attracts. ${ }^{57}$ Customary title is fragmented amongst numerous community members and this 'dissection' reduces its potential utility as a 'credit' resource. ${ }^{58}$ Further, its inalienable status has meant that it cannot be treated as a transactional resource and is therefore excluded from a framework where exchange is the basic denomination. ${ }^{59}$

\footnotetext{
${ }^{55}$ Waldron above $\mathrm{n} 52$.

${ }^{56}$ This is examined by R Strickland, 'The Genocidal Premise in Native American Law and Policy: Exorcising Aboriginal Ghosts' (1998) 1 Journal of Gender Race and Justice 325 where the author concludes that American Indian law and policy is governed by a genocidal premise perceived to be humanitarian in nature.

${ }^{57}$ See H Demsetz, 'Toward a Theory of Property Rights II: The Competition Between Private and Collective Ownership' (2002) 31 Journal of Legal Studies 653 where it is suggested that private ownership is inherently efficient.

${ }^{58}$ See the media release: 'Land Systems holds us Back', Sydney Morning Herald, 7 December, 2004 where the 'need to move away from communal land ownership and non-profit community businesses and take up home ownership, economic land development and profit-making businesses' was raised by Warren Mundine (a member of the National Indigenous Council: see further Australian Institute of Aboriginal and Torres Strait Islander Affairs

http://ntru.aiatsis.gov.au/research/resourceguide/PDF_FILES/Current $\% 20$

Debates\%20Indigenous\%20Land\%20Tenure.pdf

${ }^{59}$ See the classic discussion by G Calabresi and A D Melamed, 'Property Rules, Liability Rules, and Inalienability: One View of the Cathedral' (1972) 85 Harvard Law Review 1089, 1094 where the authors note that economic efficiency 'asks for
} 
Normative economic analysis suggests that common law legal rules should be efficient and promote "wealth maximization. ${ }^{60}$ Thus, law-makers should choose the legal rule that maximises the ratio of benefits to costs and this is measured according to social 'willingness-to-pay'. ${ }^{61}$ The perceived economic utility of privatised, alienable land title has a long history. William Blackstone concluded that the right to exclude is one of the most powerful features of ownership because it encourages effective resource development. ${ }^{62}$

Classic economic theory supports this premise arguing that private ownership promotes wealth maximisation because it 'evolves toward efficiency. "' It encourages effective resource management and 'costjustified fragmentation' of land interests because these processes complement the self-interest of individual title holders. ${ }^{64}$ Thus, private ownership is perceived as stimulating efficient management, conservation, investment and conflict resolution over land. ${ }^{65}$

that form of property, private or communal, which leads to the highest product for the effort of producing'.

${ }^{60} \mathrm{R}$ A Posner, Economic Analysis of Law ( $\left.1^{\mathrm{st}} \mathrm{ed}, 1973\right)$; R.A Posner, "Utilitarianism, Economics and Legal Theory," (1979) 8 Journal of Legal Studies 103; R A Posner, 'The Ethical and Political Basis of the Efficiency Norm in Common Law Adjudication' (1980) 8 Hofstra Law Review 487; R A Posner, 'Wealth Maximization Revisited' (1985) 2 Notre Dame Journal of Law, Ethics, and Public Policy 85; R A Posner, The Problems of Jurisprudence (1990).

${ }^{61}$ See R A Posner, 'Wealth Maximisation Revisited' above n 60, esp 100-102.

${ }^{62}$ Commentaries on the Laws of England, (first published, 1765), Bk II.

Blackstone concluded that it is the private nature of ownership, the 'despotic dominion' which is 'in total exclusion of the right of any other individual in the universe' which explains the 'pains to till and work the earth.' See also, Carol M Rose, 'Canons of Property Talk, or, Blackstone's Anxiety Essay' (1998-1999) 108 Yale Law Journal 601; Carol M Rose, 'The Comedy of the Commons: Custom, Commerce and Inherently Public Property' (1986) University of Chicago Law Review 711.

${ }^{63}$ See H Demsetz, 'Toward a Theory of Property Rights' (1967) American Economic Review 347 and also T W Merrill, 'Introduction: The Demsetz Thesis and the Evolution of Property Rights' (2002) 31 Journal of Legal Studies 331 for a re-evaluation of the Demsetz thesis.

${ }^{64}$ See the discussion by R Wade, 'The Management of Common Property Resources: Collective Action as an Alternative to Privatisation or State Regulation' (1987) 11 Cambridge Journal of Economics 95,102.

${ }^{65}$ It is argued that the rights 'that give one person (the owner) the ability to exclude all other claimants to the resource' is the most effective method of resolving resource conflict: See T W Merrill and H E Smith, 'What Happened to Property in Law and Economics?' (2001) Yale Law Journal 357, 374. 
From a Western perspective, the primary economic impediment of customary title is its inalienable status. ${ }^{66}$ This feature has, it is argued, retarded its economic progress. ${ }^{67}$ Communal, 'non-private' ownership, incapable of commodification is perceived to inevitably progress toward a 'tragedy of the commons' scenario, where 'common' land is improperly, and inefficiently managed and under-invested. ${ }^{68}$

However, these are cultural perceptions. They stem from a dominant property ontology where ownership is conflated with wealth. It should not be forgotten that customary ownership has its own ontological imperatives. For indigenous Australians, land is not traditionally perceived as a commodity. ${ }^{69}$ It is a complex, inter-layered relationship where excludability and alienability are cultural externalities. Ownership for many indigenous communities is sourced in de-centralised concepts of kinship, welfare and identity. Customs reflect community interest and social cohesion. ${ }^{70}$

Economic models that predict outcome and measure efficiency cannot respond to customary ownership because of its fundamentally different cultural denotation. Indeed, economic revisionists such as Kaplow and Shavell, have argued that pluralist property cultures would be more appropriately embraced by broader economic models incorporating

\footnotetext{
${ }^{66}$ This is discussed in the classic thesis by Calabresi and Melamed, 'Property Rules, Liability Rules and Inalienability: One View of the Cathedral' (1972) 85 Harvard Law Review 1089.

${ }^{67}$ The difficulties experienced by inalienable communal ownership were examinated by N K Komesar, Laws, Limits: The Rule of Law and the Supply and Demand of Rights (2001) where it is suggested that inalienability and fragmentation have constrained the capacity of common ownership to enforce title producing conflict and economic exclusion. See also R A Posner, Economic Analysis of the Law $\left(6^{\text {th }}\right.$ ed, 2003) 32-34 where the economic consequences of the 'tragedy of the commons' is examined.

${ }^{68}$ See Hardin, 'The Tragedy of the Commons' (1968) 162 Science 1234 reprinted in B Ackerman (ed), Economic Foundations of Property Law (1975) 2.

${ }^{69}$ See F Von Benda-Beckman, 'Anthropological Approaches to Property Law and Economics' (1995) 2 European Journal of Law and Economics 309 where anthropological rather than economic relationships between indigenous inhabitants and the land are discussed.

${ }^{70}$ See in particular the discussion by L Strelein, 'Conceptualising Native Title' (2001) 23 Sydney Law Review 95, 99 where the author states: 'Native Title involves concepts that are not traditionally the domain of the Australian courts, such as collective rights, legal pluralism, and issues of competing sovereignty.'
} 
welfarism instead of cost-benefit analysis. These theorists suggest that courts and legislators should assume a diverse, welfare-oriented approach to title assessment. Wealth maximisation and economic benefit would not be entirely discounted within such an analysis but would becomes one of a range of factors where, in the language of Kaplow and Shavell, "notions of fairness become independent evaluative principles. ${ }^{, 71}$

The economic justifications that purportedly support a shift from customary to individualised ownership overlook the evolved pluralism of the Australian landscape and 'lose sight' of the 'distinct boundaries' between private and non-private ownership. ${ }^{72}$ Western private property may progress inevitably toward 'efficiency' within a society where it is viewed as an item of consumption but the same cultural conditions do not necessarily apply to 'privatised' customary ownership. The cultural boundaries between private and non-private property are fundamentally different. In the words of Michael Heller:

Conflating the economic language of entitlement with the language of property rights causes theorists to collapse inadvertently the boundaries of private [and non-private] property. ${ }^{73}$

International experiences with title individuation policies have clearly revealed that 'privatised' customary ownership does not progress towards efficiency. ${ }^{74}$ There are a variety of reasons for this however the most obvious stems from cultural dislocation. Indigenous owners, unfamiliar and inexperienced with the alienation process, may rapidly dissipate private title to non-indigenous owners and dramatically reduce customary land holdings. ${ }^{75}$

${ }^{71}$ Kaplow, Louis and Shavell 'Fairness versus Welfare' (2001) 114 Harvard Law Review 96. See also Lewis A Kornhauser, 'Governance Structures, Legal

Systems, and the Concept of Law' (2004) 79 Chicago-Kent Law Review 355.

${ }^{72}$ The boundaries inherent in private property are examined by M A Heller, 'The Boundaries of Private Property' (1999) 108 Yale Law Journal 1163 especially at 1193.

73 This is discussed by M A Heller, 'The Boundaries of Private Property' (1999)

108 Yale Law Journal 1163, especially at 1194.

${ }^{74}$ See for example the discussion by J V Royster, 'The Legacy of Allotment' (1995) 27 Arizona State Law Journal 1, 3 where the author notes that the 'allotment policy was a failure. It did not transform the Indians into yeoman farmers, but it did wreak destruction within tribal communities.'

${ }^{75}$ For example, in the United States, allotments made under the Dawes Act (General Allotment Act 1887 are estimated to have caused the loss of 
This can produce a 'checkerboard' pattern of indigenous and nonindigenous tenure and customary holdings over large tracts of land. This, in turn has the effect of reducing overall title value, impeding cultural continuity over remaining customary ownership areas and accelerating community disintegration. ${ }^{76}$

The land itself may be arid and inaccessible with little economic utility. Title individuation cannot change the physicality of the land and previous experience has revealed that individuation can do nothing to alter this indelible fact. Historically, private banks have shown an inherent reluctance to provide credit for individualised customary title because of such physicality factors and also because of the fractionalised status of the title itself. ${ }^{77}$

Customary land which is individualised invariably ends up being owned by multiple tenants in common, a position which can increase exponentially through successive inheritance. Eventually, as evident in the American Indian experience, thousands of individual owners claim small, separate sections of land which were previously maintained holistically in accordance with community customs. ${ }^{78}$ These small segmented interests have little if any investment potential. ${ }^{79}$

approximately 36.5 million hectares of Indian land prior to its repeal in 1934 under the Indian Reorganisation Act. Much of this was a consequence of fraudulent, misunderstood or corrupt transactions: see Mazurek (ed), American Indian Law Deskbook (1998) 21.

${ }^{76}$ See especially J V Royster, 'The Legacy of Allotment' (1995) 27 Arizona State Law Journal 1.

${ }^{77}$ In the context of New Zealand, this is discussed by R Boast in

'Individualisation - An Idea Whose Time Came and Went: The New Zealand Experience' a paper given at July 2006 Native Title Workshop, 'Trends Toward Individual Title over Communal Lands: Implications For Resource Management and Sustainability' University of Melbourne. He notes that the 'hoped for benefits of individualisation ... singularly failed to happen. Private banks proved very unwilling to lend money on the security of Maori freehold land, even though it was now a freehold and included within the Land Transfer system.'

${ }^{78}$ In the United States many individual titles held under trust could not be alienated or partitioned compounding the problem. This was discussed by $\mathrm{F}$ Hoxie, A Final Promise: The Campaign to Assimilate the Indians, 1880-1920 (1984) especially at 165.

${ }^{79}$ See M Lindo, 'Youpee v Babbit - The Indian Land Inheritance Problem Revisited' (1997) American Indian Law Review 223 at 225 where the author notes: 'Due to problems created by multiple ownership of undivided interests in Indian trust land, such land has sometimes been all but abandoned.' 
The need to 'privatise' communal ownership generally occurs, according to economic theory, when technical, population and other pressures strain the capacity of common resources and the need to 'internalize externalities' arises. ${ }^{80}$ The individuation of customary ownership does not fit within this paradigm. Cultural 'externality' is not a resource pressure. Economic models that assume a 'commodity' value for title ignore the importance of community, tradition and cultural continuity. Economic prosperity and well-being for indigenous communities is achievable without having to destroy the cultural nucleus of customary ownership.

To justify the individuation of customary ownership on economic grounds is to enframe indigenous perspectives with Western ownership imperatives. These imperatives are not sourced in indigenous ontology and cannot respond intuitively to a framework where ownership is not perceived in terms of individualistic entitlement and wealth. Their application to the individuation process only serves to dislocate the cultural foundations of customary ownership.

\section{LESSONS From Other COUNTRIES}

The experiences of title individuation in other countries provide valuable lessons for Australia. In most instances, the process has resulted in the devastation of customary ownership, the marginalisation of indigenous community members, the creation of splintered and complex private ownership patterns, an acceleration of the loss of customary lands to nonindigenous holders and the obliteration of culturally specific ontological perspectives.

\footnotetext{
${ }^{80}$ H Demsetz, 'Towards a Theory of Property Rights' (1967) 57 American Economic Review 347, 350-353. This theory has been challenged because it is argued that it ignores other factors such as government policies, market failures and individual preferences: see M A Heller, 'The Boundaries of Private Property' (1999) 108 Yale Law Journal 1163, especially at 1194. See also D Fitzpatrick, 'Evolution and Chaos in Property Rights Systems: The Third World Tragedy of Contested Access' (2006) 115 Yale Law Journal 996.
} 


\section{A The United States}

During the $19^{\text {th }}$ century, communal land reserves held by American Indians were 'individuated' under allotment legislation which eventually resulted in individual Indian allottees acquiring fee simple grants over the allotted land. ${ }^{81}$

The allotment policy in the United States was based upon the assumption that

individual ownership of property would turn the Indians from a savage, primitive, tribal way of life to a settled, agrarian, and civilised one. Assimilation was viewed as both humanitarian and inevitable. The cornerstone of this social engineering, this 'legal cultural genocide' was the replacement of tribal communal ownership of land with private property. ${ }^{82}$

The United States experience clearly reveals the problems involved in the assumption that relationships with the land which are founded in indigenous cultural perspectives should be 'reclassified' and 'redistributed' under individual titles .

One of the enduring legacies of the allotment experience was that of 138 million acres of Indian reservation land held in 1887, only 90 million acres remained by the end of the allotment program in $1934 .{ }^{83}$ As noted by the Meriam Report, a non- governmental study investigating the effect of Indian policy and administration on Indian life, loss of Indian landholdings occurred via the fragmentation of interests held under federal trusts and the loss of fee patents through fraud, corruption and financial destitution. ${ }^{84}$

\footnotetext{
${ }^{81}$ See the General Allotment Act 1887 (US). Communal reservation land subject to an allotment was held by the public trustee for 25 years and was inalienable during this period. After the expiration of 25 years the land was transferred to individual allottees in fee simple. For an excellent overview of this see:

${ }^{82}$ See J V Royster, 'The Legacy of Allotment' (1995) 27 Arizona State Law Journal 1, 6.

${ }^{83}$ This is discussed by T L Anderson, Sovereignty Nations or Reservations? An Economic History of American Indians 1995 and see generally $\mathrm{F} \mathrm{E}$ Hoxie, $A$ Final Promise: The Campaign to Assimilate the Indians, 1880-1920, 1984.

${ }^{84}$ Institute for Government Research, The Problem of Indian Administration, (L. Meriam ed, 1928). Brief excerpts of the Meriam Report are reprinted in F P Prucha (ed), Documents of United States Indian Policy, (2 ${ }^{\text {nd }}$ ed,1990) 219-221.
} 
One of the central features of the General Allotment Act was the fact that individual allottees received lands in fee however Congress held the allotted lands in trust for a period of twenty-five years. ${ }^{85}$ The purpose of this trust period was to enable the allottee to undergo 'cultural assimilation' and develop non-indigenous approaches to agriculture, Christianity and citizenship. ${ }^{86}$ At the expiration of the twenty-five year period the individual would receive an unencumbered patent in fee. Once the patent in fee was issued, the land could be alienated, encumbered and taxed. $^{87}$

The result of this was that upon the issuing of the fee patent, many thousands of Indians disposed of their land pursuant to voluntary or fraudulent sales or through resumption for non-payment of taxes or other government imposed liens. ${ }^{88}$ By 1934 two-thirds of all land allotted was owned by non-Indians. ${ }^{89}$

Fee patented land was never restored to customary ownership. The vast majority of lands that passed into fee during the allotment period remain that way today and the enduring 'legacy' of allotment lies in the fact that customary, tribal ownership of lands acquired by non-Indians pursuant to the allotment programme has not been revived. ${ }^{90}$ Courts in the United States have held that 'the inherent sovereign powers of an Indian tribe do not extend to the activities of non-members of the tribe' so that effectively,

${ }^{85}$ General Alllotment Act, ch.119,s5,24 Stat.389 (1887). This is discussed by D S Otis, TheDawes Act and The Allotment of Indian Lands (F P Prucha (ed), 1973 esp at 50.

${ }^{86}$ See D S Otis, above.

${ }^{87}$ The taxation of fee patents was examined by the court in County of Yakima Indian Nation (1992) 502, U.S. 251.

${ }^{88}$ See J A McDonnell, The Dispossession of the American Indian, 1887-1934 (1991) at 100-107.

${ }^{89}$ This is discussed by F S Cohen, Handbook of Federal Indian Law, first published 1941 (US Government Printing Office), $19454^{\text {th }}$ printing at 216where the author notes: 'Through the sales by the Government of fictitiously designated 'surplus' lands; thought sales by allottees after the trust period had ended or been terminated by administrative act and through sales by the Government of heirship land, virtually mandatory under the allotment act: through these three methods the total of Indian landholdings has been cut from 138,000,000 acres in 1887 to $48,000,000$ acres in 1934 .'

${ }^{90}$ This is discussed by J V Royster, 'The Legacy of Allotment' (1995) 27 Arizona State Law Journal 1. 
inherent sovereign powers of indigenous Indians were abrogated by the operation of the General Allotment Act. ${ }^{91}$

\section{B New Zealand}

In New Zealand, Maori ownership has a very strong history of title individuation. Customary lands not coming within the application of the initial Native Land Acts in 1862 were investigated by the Land Court and, where approved, ownership was transformed into what came to be referred as 'Maori freehold title'.

The Native Lands Act 1865 established the Native Land Court, now referred to as the Maori Land Court, which was introduced with the basic function of identifying valid Maori customary title and recording ownership and dealings in Maori Land. Section 6 of the Native Land Court Act 1865 set out that it was expedient to encourage the extinction of Maori proprietary customs and provide 'for the conversion of such modes of ownership into titles derived from the Crown'. From this time onwards, the principal manner in which Maori customary title was extinguished was through the operation of the Court in investigating ownership and granting freehold titles. ${ }^{93}$

The court had the power to identify the rightful customary owners of land and issue a certificate of title to the appropriate community, tribe or individual. This certificate of title could then, in turn, be exchanged for a Crown grant of freehold title. ${ }^{94}$ The title was issued in the form of an individualised estate and was given to individual indigenous owners as tenants in common. This meant that Maori title automatically became alienable. Purchasers could acquire an undivided share of an area of Maori freehold and partition orders were issued through the Native Land Court. ${ }^{95}$

\footnotetext{
${ }^{91}$ Montana $v$ United States (1981) 450 U.S. 544, 566 commenting on the effect of the decision in Oliphant $v$ Suquamish Indian Tribe (1978) 435 U.S. 191.

${ }^{92}$ See generally: F M Brookfield, Waitangi and Indigenous Rights, Revolution, Law and Legitimation, 1999 especially 166-186.

${ }^{93}$ This is set out in: Native Land Act 1862; Native Lands Act 1865 - currently outlined in Te Ture Whenua Maori Act ( Maori Land Act 1993), ss 6 and 17.

${ }^{94}$ Native Lands Act 1865 ss5 and 46.

${ }^{95}$ See the discussion by J Binney, 'The Native Land court and the Maori Communities' in J Binney, J Basset and E Olssen (eds) The People and the Land: Te Tangata me te whenua: An Illustrated History of New Zealand 1820-1920 (1990), especially 140-146.
} 
Thus, once Maori freehold was issued, settlers were able to negotiate a purchase of the land with individual Maori holders. Inevitably, this had a dramatic impact upon Maori landholdings. As discussed by Richard Boast:

Titles were subject to constant attribution from the Crown's land purchaser officers and from private buyers, creating attendant risks of costly partition hearings in the Native Land court and the need for fresh surveys....the immediate pressures of debt and poverty that confronted the Maori population in the second half of the nineteenth century were so pressing that there were strong incentives to sell at less than market values. ${ }^{96}$

While on the face of it the Native Land Court appeared to promote the regulation of Maori customary title, the true purpose was the facilitation of settler purchases via the exchange of customary title for freehold title. ${ }^{97}$ The preamble to the legislation setting up the Native Land Acts clearly stated that the policy of the act was to "encourage the extinction of such proprietary customs and to provide for the conversion of such modes of ownership into titles derived from the Crown. ${ }^{98}$ Maori customary title was perceived as ownership only to the extent that it qualified the holder to apply for a tenured estate. ${ }^{99}$ Thus, the Native Land Court became 'an inexorable mechanism for conversion of customary land into freehold land. ${ }^{100}$

Significantly, the process of individuating Maori customary ownership occurred despite the apparent legislative protection of their interests under section 4 of the Native Rights Act 1865 which read as follows:

\footnotetext{
${ }^{96}$ From a paper given at the 2006 Native Title Workshop: 'Trends Toward Individual Title Over Communal Lands: The Implications For Resource Management and Sustainability.' The paper given by Richard Boast is titled: 'Individualisation - An Idea Whose Time Came, and Went: The New Zealand Experience' and will be included within the forthcoming book: Buying The Land, Selling the Land: Governments and Maori Land in the North Island 1865-1921 to be published by Victoria University Press in 2006.

${ }^{97}$ See generally K Sinclair, The Origins of the Maori Wars $\left(2^{\text {nd }}\right.$ ed, 1961) 238. See also more generally A Ward, A Show Of Justice: Racial Amalgamation in Nineteenth Century New Zealand (1973) especially 130-131.

${ }^{98}$ Preamble to the Native Lands Act 1865.

${ }^{99}$ For an excellent discussion on the impact of the common law on indigenous land rights see generally: R A Epstein, 'Property Rights Claims of Indigenous Populations: The View from Common Law' (1999) 31 University of Toledo Law Review 3.

${ }^{100}$ Ngati Apa v Attorney-General [2003] 3 NZLR 643 at [45] per Elias CJ.
} 
Every title to or interest in land over which the Native title shall not have been extinguished shall be determined according to the Ancient Custom and Usage of the Maori people so far as the same can be ascertained.

Successive Maori land legislation contains similar 'transfer' provisions. Under the current Te Ture Whenua Maori Act 1993, section 141(1)(b) sets out that where a vesting order has been registered with the District Land Registrar, customary title should be transformed into fee simple title in the same manner 'as if the land had been granted to those persons by the Crown'. However, the legislation no longer makes this transformation automatic. Under section 132 of Te Ture Whenua Maori Act 1993, Maori customary title will become freehold title where a vesting order is issued. It is possible, under section 131, for the Maori Land Court to issue an independent customary title declaration, however the combined effect of pre-emptive Crown purchases of land and the individuation of Maori customary title has meant that there is very little customary ownership left in New Zealand. ${ }^{101}$

The individualisation of Maori title was initiated during a period when it complemented colonial land policy. Its ultimate effect has been unqualified. As noted by Richard Boast, " $[t]$ he machine was allowed to run until there was nothing left to individualise; nor has the remaining stock of Maori freehold land ever been de-individualised at any time, and such a project would now be politically impossible in the face of owner opposition. $^{102}$

Today, customary ownership in New Zealand is effectively non-existent. Recently, the New Zealand Court of appeal in Attorney-General v Ngati Apa considered whether Maori customary ownership existed over one of the few remaining coastal areas not previously acquired by either the Crown or non-indigenous owners. ${ }^{103}$ Whilst the court validated the continuation of customary Maori ownership where they had not been lawfully extinguished, this decision was subsequently overruled. The Foreshore and Seabed Act 2004 sets out clearly in s13(1) that the 'full

${ }^{101}$ See generally: FM Brookfield, 'Maori Customary title in Foreshore and Seabed' [2004] New Zealand Law Journal 34

${ }^{102}$ See R Boast, 'Individualisation - An Idea Whose Time Came, and Went: The

New Zealand Experience' above n 68.

${ }^{103}$ [2003] 3 NZLR 643. See also FM Brookfield, 'Maori Customary Title In

Foreshore and Seabed' [2004] New Zealand Law Journal 34. 
legal and beneficial ownership of the public foreshore and seabed is vested in the Crown, so that the public foreshore and seabed is held by the Crown as absolute property. ${ }^{104}$

This legislation has completed a process initiated during colonial times: the eradication of customary ownership. Subject only to the possibility of indigenous holders acquiring non-proprietary 'customary orders' under the Foreshore and Seabed Act 2004, the New Zealand land system is now, effectively, univocal. ${ }^{105}$ Title individuation of Maori customary ownership ultimately came to represent its complete destruction.

\section{CONCLUSIONS}

The proposals permitting individuation of customary ownership in the Northern Territory represent the first stage in a process of cultural and proprietary desecration, clearly apparent in the experiences of indigenous communities within other countries. If those experiences have taught us anything, it is that the solution to the significant problems of poverty and marginalisation facing indigenous communities do not lie in the subversion of customary ownership. Title individuation policies within the United States and New Zealand have not improved economic conditions. Their primary effect has been the acceleration of land loss and the abolition of indigenous communities as 'autonomous and integral sociopolitical entities. ${ }^{106}$

Australia must strive to uphold the validity of customary native title as a unique and fundamentally different cultural concept, founded on indigenous 'recognition' and sourced 'in a set of understandings that remain past the ends of the outsiders' fingertips. ${ }^{107}$ The cathedral has

\footnotetext{
${ }^{104}$ See also s14 (1) and for customary orders ss32-39.

${ }^{105}$ For a further discussion on this see: R Boast, 'Maori Property Claims to the Foreshore and Seabed after Ngati Apa' (2004) 21 New Zealand University Law Review 1 and for a discussion on the constitutional implications and the relevance of the Treaty of Waitangi see B V Harris, 'The Treaty of Waitangi and the Constitutional Future of New Zealand' (2005) 2 New Zealand Law Review 189. ${ }^{106}$ See S L Pevar, The Rights of Indians and Tribes (1996) 5. See also W. Bradford, "With a Very Great Blame on Our Hearts": Reparations, Reconciliation and an American Indian Plea For Peace with Justice' (2002) 27 American Indian Law Review 1.

${ }^{107}$ B Bryan, 'Property as Ontology: On Aboriginal and English Understandings of Ownership' (2000) 13 Canadian Journal of Law and Jurisprudence 3, 10.
} 
many standpoints, each as valid as the other. The temptation to order indigenous perspectives to accord with the dictates of a different ownership framework must be avoided. We have created room for native title, we must respect that space. 